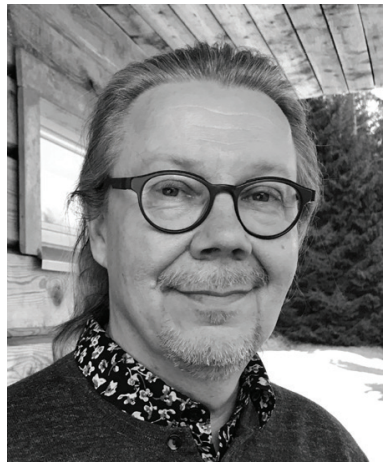

TORSTI HYYRYLÄINEN

\title{
Mitä maaseutututkimus on?
}

DOI: https://doi.org/10.51807/maaseutututkimus.111976

Y

leinen vastaus otsikon kysymykseen on: maaseutututkimus on monitieteinen tutkimusala. Lähtökohtaisesti maaseutututkimus on tieteellistä tutkimusta, joka täyttää akateemisen tutkimuksen yleiset, avoimuuden, kriittisyyden, systemaattisuuden ja totuuteen kurottautumisen kriteerit.

Aika ajoin on syytä itsereflektioon, oman tutkimusalan tilannearvioon ja maaseutututkimuksen kuvailuun niin itselle kuin alan ulkopuolisille toimijoille. Kokeneemmille tutkijoille kysymys maaseutututkimuksen olemuksesta ei ole samalla tavalla merkityksellinen kuin tutkijanuransa alussa oleville tutkijoille, jotka miettivät suhdettaan tähän tutkimusalaan.

Tieteellinen tutkimus on sosiaalisesti tuotettua todellisuutta, ja tiede on kollektiivisen toiminnan tulosta. Tutkimusta ei myöskään voi erottaa tutkijoista. Näin maaseutututkimukseen pätee muiden alojen lailla - osittain - lausuma, että maaseutututkimus on sitä, mitä alan tutkijat tekevät. Tuokaan luonnehdinta ei ole aukoton, koska maaseututukimusta voi luonnollisesti tehdä myös identifioitumatta (vain) maaseutututkijaksi.

En seuraavassa käsittele tieteen yleisiä periaatteita, vaan kuvailen maaseutututkimuksen luonnetta yleisesti pohtimalla tutkimusalan suhdetta 
alueisiin, ilmiöihin, teorioihin ja menetelmiin sekä lopuksi ongelmanasettelun erityisyyteen ja sen merkitykseen tutkimusalan kannalta.

Aluekontekstin kautta määriteltynä maaseutututkimus on tutkimusta, joka kohdistuu maaseuduiksi määriteltyihin alueisiin. Tämä luonnehdinta nojaa maantieteelliseen (kartografiseen) ja empiiriseen maaseudun määrittelyyn. Tilastollisesti maaseutualueiden keskeisenä määreenä käytetään yleensä alhaista väentiheyttä. Maaseuduksi määriteltyihin alueisiin liittyvä tutkimus ei kuitenkaan aina kytkeydy maaseutututkimuksen piirissä käytyihin keskusteluihin tai tutkimusongelmiin. Pelkällä aluekriteerillä tutkimuksen piiristä rajautuisi kiinnostavia maaseutua koskevia kysymyksenasetteluja, joita tutkitaan kaupungeissa. Esimerkiksi Kaskista ei pidä rajata pois maaseutututkimuksen piiristä vai siksi, että se on määritelmällisesti pieni kaupunki. Toisaalta suuri osa maataloustutkimusta olisi vain aluekontekstin kautta määriteltynä itsestään selvästi maaseutututkimusta. Aluekonteksti onkin yksin riittämätön maaseutututkimuksen määre.

Ilmiölähtöinen lähestymistapa tarkoittaa tässä yhteydessä, että olisi olemassa joitain maaseutututkimuksen kannalta erityisen kiinnostavia tai keskeisiä ilmiöitä, joita tutkimusalalla olisi syytä syvällisesti ymmärtää. Tämäkin näkökulma johtaa vaikeisiin jatkokysymyksiin: mitä nämä ilmiöt olisivat? Millä perusteella esimerkiksi köyhyydestä tulisi erityinen maaseutututkimuksen tutkimuskohde? Vastausta voisi hakea siitä, että ilmiö on yleinen maaseuduiksi määriteltävillä alueilla. Köyhyyden osalta näin voi olla, mutta mitenkään erityisesti maaseutututkimuksen määritelmällisessä ytimessä oleva ilmiö köyhyys ei ole. Toisaalta on totta, että jotkin aluekehityksen ilmiöt, kuten kasvun kasautuminen, ovat maaseudun näkökulmasta keskeisiä. Ilmiölähtöisyys onkin (ehdollisesti) merkittävä maaseutututkimuksen määrittäjä.

Maaseutututkimuksen on usein luonnehdittu sitoutuvan maaseudun muutoksen (rural change) tutkimiseen. Tätä selittänee se, että maaseutu on aina ollut muutoksessa, ja teollistumisen ajoista lähtien tuo muutos on ollut luonteeltaan maaseudun suhteellista asemaa heikentävä, esimerkiksi maaltamuuton seurauksena. Vaikka maaseutututkimuksissa usein kuvataan muutosta ja siihen liittyviä ilmiöitä, syitä ja seurauksia, on vaikeata nähdä muutoksen tutkimusta erityisen ominaisena vain maaseutututkimukselle. Toisaalta tietämys esimerkiksi joistakin niin sanotuista alueellisen kehityksen ja erilaistumisen kehitysteorioista (transition 
studies) voidaan perustella tarpeelliseksi maaseutututkijan työkalupakkiin. Mutta myös tämä on lausuttava varovaisen ehdollisena määreenä.

Teoriat ja menetelmät ovat tieteellisen tutkimuksen kovinta ydintä. Onko maaseutututkimuksella omaa teoreettista tai menetelmällistä perustaa? Kysymys on tuttu myös monille maaseutututkimusta lähellä oleville tutkimusaloille, kuten kaupunkitutkimukselle tai aluetutkimukselle, joiden emotieteenä voi pitää maantiedettä. Eri suuntauksineen maantiede tarjoaa niille runsaasti teoreettisia ja menetelmällisiä kiinnekohtia.

Maaseutututkimuksen osalta voi todeta, että menetelmien ja teorioiden kohdalla on merkittävää tutkimusalan oma perintö, eli se, miten paljon on kertynyt alan omaksi miellettyä ja siinä hyödynnettyä teoreettista ja menetelmällistä kirjallista kerrostumaa, johon voidaan yhä uudestaan viitata ja jota voidaan alan tutkimuksissa uusintaa.

Maaseutututkimuksessa ei ole ollut luonnollista pakkoa synnyttää omaa teoriaa, saati omia menetelmiä laajan olemassa olevan yhteiskuntatieteellisen arsenaalin ohi tai sen päälle. Jos jokin teoria, kuten esimerkiksi kasautuvan kasvun teoria tai tilastollinen / laadullinen menetelmä puhdistetaan käyttöyhteydestään puhtaaksi tieteen työkaluksi, niin maaseutututkimuksen omista menetelmistä ei ole perusteita puhua. Maaseutututkimuksessa teorioita ja menetelmiä lainataan muilta aloilta ja niitä käytetään ongelmalähtöisesti. Maaseutututkijan työkalupakissa on parhaimmillaan monipuolinen valikoima välineitä tutkimuksen tekemiseen. Oikeiden työkalujen valitsemista ohjaa ongelmanasettelu.

Ongelmanasettelun erityisyys maaseutututkimuksessa on kiinnostava näkökulma sillä rajauksella, ettei siinä voida poiketa tieteellisen ongelmanasettelun yleisistä periaatteista: sen pitää olla kaikilta osin läpinäkyvää ja avointa. Jokaisella tutkimusalalla on omia ongelmanasettelun perinteitään, ja samantyyppiset tutkimusasetelmat ja -kysymykset toistuvat tutkijasukupolvesta toiseen. Lisäksi vanha totuus siitä, että tärkeintä tutkimuksessa on löytää oikea ongelma, pitää edelleen paikkansa. Onko siis olemassa maaseutututkimukselle tyypillisiä ongelmia tai tutkimuskysymyksiä, vai onko kyse näkökulman valitsemisesta?

Ongelmanasettelu konkretisoituu erityisesti tutkimussuunnitelmassa: mitä, miksi ja miten jotain kiinnostavaa ilmiötä tai muutosta tutkitaan? Tuossa tilanteessa tutkijalla on usein tiedossaan ja käytössään elementtejä aluekontekstista, ilmiöstä sekä teorioista ja menetelmistä. Ne eivät 
kuitenkaan itsessään tee tutkimuksesta maaseutututkimusta, koska ne ovat pääosin yhteisiä muiden tutkimusalojen kanssa. Ongelmanasettelu onkin keskeinen käytännön tutkimusprosessia ohjaava pohdinta, jossa tutkimus rakentuu maaseudun näkökulmasta kiinnostavaksi asetelmaksi ja kohdistuu kiinnostaviin kysymyksiin.

Tutkimusongelma muotoutuu edellä kuvattujen elementtien ristivaikutuksessa. Parhaimmillaan kyse on luovasta toiminnasta, jossa tutkija käyttää tietojaan ja taitojaan sekä yhdistelee erilaisia elementtejä saavuttaakseen kiinnostavan tutkimusasetelman. Alasta riippumatta tutkijat joutuvat aina tekemään myös perusteltuja rajauksia, jotka ovat pohjimmiltaan arvovalintoja.

Tutkimusasetelman muotoilu tapahtuu nykyisin yhä useammin tutkimusryhmässä, parhaimmillaan osana monitieteistä tutkijadialogia. Käytännössä on aina myös muita laajempia tutkimusyhteisön kulttuurisia tekijöitä, jotka voivat vaikuttaa tutkimusasetelman rakentumiseen. Myös tutkimuksen rahoittajan, tilaajan tai mahdollisen hyödyntäjän näkökulmat voivat vaikuttaa asetelmaan.

Edellisten lisäksi maaseutututkimusta luonnehditaan usein monitieteisyyden ja tieteidenvälisyyden termein. Niiden tavoittelu onkin tyypillistä juuri laaja-alaisille ja joustavarajaisille tutkimusaloille. Monitieteisyys tuo kuitenkin mukanaan uusia kysymyksiä, jotka haastavat maaseutututkimuksesta esitettävän kuvan selkeyden. Tietyt tutkimusalat tulevat luonnostaan erityisen lähelle maaseutututkimusta.

Eron tekeminen maatalous- ja metsätieteelliseen tutkimukseen ei nähdäkseni perustu muuhun kuin siihen 1950-luvulta käynnistyneeseen muutokseen, jossa osana maaseutututkimuksen omaa identiteettityötä tehtiin tietoista eroa maatalous- ja metsätieteiden vahvaan perintöön. Perusteluna oli lyhyesti sanoen se, että ne nähtiin liian kapea-alaisina selittämään maaseudun muutosta kokonaisuutena.

Maaseutututkimus kuvataan yleensä ihmis- ja yhteiskuntatieteelliseksi tutkimusalaksi, jossa voi olla aineksia myös luonnontieteellisestä tutkimuksesta. Ihmistieteellisen ja luonnontieteellisen tutkimuksen suhteet maaseutututkimuksessa ovatkin tapauskohtaisesti tarkentuvia kysymyksiä. Tämä ainesten limittyminen on jopa toivottavaa maaseutututkimuksen elinvoimaisuuden kannalta. Viime aikojen keskustelu ihmisen ja 
luonnon erottamattomuudesta on hyvä lisäperustelu tieteidenvälisen vuorovaikutuksen vahvistamiselle.

Perustutkimuksellisen ja soveltavan tutkimuksen otteiden suhde maaseutututkimuksessa on niin ikään tapaus- ja tutkijakohtainen kysymys. Kyseinen erottelu on yhteiskuntatieteissä yleisesti hämärärajainen. Käytännössä eri tutkijoilla on erilaisiin tutkimusotteisiin erilainen palo, eikä tämä jaottelu nouse siten oleelliseksi maaseutututkimuksenkaan kannalta: molemmat otteet ovat sekä mahdollisia että toivottavia. Soveltavan tutkimuksen ote lienee useimmilla tutkimusaloilla - kuten maaseutututkimuksessakin - yleisempää kuin perustutkimus.

Elintärkeäksi tutkimusalan olemuksen ja olemassaolon selittäjäksi voidaan oman perinteen lisäksi nostaa alan toimijoiden kyky tuottaa uutta tietoa. Alan elinvoimaisuuden ehtona on lisäksi tutkimuksen yhteiskunnallinen relevanssi, eli tutkimusalalla on kyettävä joustavasti tarttumaan kiinnostaviin, yhteiskunnallisesti tärkeisiin kysymyksiin. Näin ajateltuna maaseutututkimus on monitieteinen tutkimusala, joka kohdistuu erilaisten maaseutujen näkökulmasta kiinnostaviin kysymyksiin.

Maaseutututkimuksella on Suomessakin perinteensä, omat instituutionsa ja uusintamisen muotonsa (julkaisut ja yhteisöt). Lisäksi alan tutkijat työskentelevät maaseutututkimuksen ja tieteen kansainvälisissä verkostoissa. Näiden kanavien kautta tieto maaseutututkimuksen monimuotoisesta kehityksestä välittyy myös Suomeen, yhteiseksi hyödyksi.

Tieteiden ja tutkimusalojen laaja kenttä on jatkuvassa uudistumisen tilassa: kilpailu on kovaa ja tilaus uusille tutkimusaloille jatkuva. Maaseutututkimuksen elinvoiman puolesta on toimittava tavoitteellisesti ja yhteistyössä. 